\title{
Simultaneous assessment of plasmatic, acrosomal, and mitochondrial membranes in ram sperm by fluorescent probes
}

\author{
[Avaliação simultânea das membranas plasmática, acrossomal e mitocondrial de espermatozoides \\ de carneiros por sondas fluorescentes] \\ E.C.C. Celeghini, J. Nascimento, C.F. Raphael, A.F.C. Andrade, R.P. Arruda* \\ Laboratório de Biotecnologia do Sêmen e Andrologia - VRA-FMVZ-USP \\ Av. Duque de Caxias Norte, 225 \\ 13635-900 - Pirassununga, SP
}

\begin{abstract}
In this experiment, it was defined a protocol of fluorescent probes combination: propidium iodide (PI), fluorescein isothiocyanate-conjugated Pisum sativum agglutinin (FITC-PSA), and JC-1. For this purpose, four ejaculates from three different rams $(\mathrm{n}=12)$, all showing motility $\geq 80 \%$ and abnormal morphology $\leq 10 \%$, were diluted in TALP medium and split into two aliquots. One of the aliquots was flash frozen and thawed in three continuous cycles, to induce damage in cellular membranes and to disturb mitochondrial function. Three treatments were prepared with the following fixed ratios of fresh semen:flash frozen semen: 0:100 (T0), 50:50 (T50), and 100:0 (T100). Samples were stained in the proposal protocol and evaluated by epifluorescence microscopy. For plasmatic membrane integrity, detected by PI probe, it was obtained the equation: $\hat{\mathrm{Y}}=1.09+0.86 \mathrm{X}\left(\mathrm{R}^{2}=0.98\right)$. The intact acrosome, verified by the FITC-PSA probe, produced the equation: $\hat{\mathrm{Y}}=2.76+0.92 \mathrm{X}\left(\mathrm{R}^{2}=0.98\right)$. The high mitochondrial membrane potential, marked in red-orange by JC-1, was estimated by the equation: $\hat{\mathrm{Y}}=1.90+0.90 \mathrm{X}\left(\mathrm{R}^{2}=0.98\right)$. The resulting linear equations demonstrate that this technique is efficient and practical for the simultaneous evaluations of the plasmatic, acrosomal, and mitochondrial membranes in ram spermatozoa.
\end{abstract}

Keywords: ovine, semen, epifluorescence microscopy, sperm membranes

\section{RESUMO}

Neste experimento, foi definida uma combinação de sondas fluorescentes: iodeto de propídio (PI), aglutinina de Pisum sativum conjugada ao isotiocionato de fluoresceína (FITC-PSA) e JC-1. Para esta proposta, quatro ejaculados de três carneiros $(n=12)$, que apresentavam motilidade $\geq 80 \%$ e alterações morfológicas $\leq 10 \%$, foram diluídos em meio TALP e divididos em duas alíquotas. Uma alíquota foi submetida a três ciclos de flash frozen e descongelação, para induzir danos nas membranas celulares $e$ distúrbios na função mitocondrial. Três tratamentos foram preparados com as seguintes proporções preestabelecidas de sêmen fresco: sêmen submetido a flash frozen: 0:100 (T0), 50:50 (T50) e 100:0 (T100). As amostras foram coradas no protocolo proposto e avaliadas por microscopia de epifluorescência. Para integridade de membrana plasmática, detectada pela sonda PI, foi obtida a equação: $\hat{Y}=1,09+0,86 X\left(R^{2}=0,98\right)$. O acrossomo intacto, verificado pela sonda FITC-PSA, produziu a equação: $\hat{Y}=2,76+0,92 X\left(R^{2}=0,98\right)$. $O$ alto potencial de membrana mitocondrial, marcada em vermelhoalaranjado pelo JC-1, foi estimado pela equação: $\hat{Y}=1,90+0,90 X\left(R^{2}=0,98\right)$. As equações lineares resultantes demonstraram que a técnica é eficiente e prática para avaliação simultânea das membranas plasmática, acrossomal e mitocondrial em espermatozoides de carneiros.

Palavras-chave: ovino, sêmen, microscopia de epifluorescência, membranas espermáticas

Recebido em 15 de julho de 2009

Aceito em 3 de maio de 2010

*Autor para correspondência (corresponding author)

E-mail: arrudarp@usp.br 


\section{INTRODUCTION}

The maintenance of the sperm fertilizing potential depend on the integrity and functionality of the different cellular structures, which in the practice, reflects in the difficulty to develop an isolate laboratorial test to predict with accuracy the semen fertility potential (Graham et al., 1990; Andrade et al., 2007; Celeghini et al., 2007). A large diversity of fluorescent probes has been developed to seminal evaluation.

The propidium iodide (PI) is a fluorescent stain used to evaluate the plasmatic membrane integrity; it has DNA affinity and stains in red the nucleus of damaged plasmatic membrane (Garner et al., 1986; Graham et al., 1990). PI is very stable, and has been used more than fluorescent probes as by epifluorescence microscopy (Garner et al., 1997; Sukardi et al., 1997; Thomas et al., 1997; Celeghini et al., 2007, 2008;), as well as by flow cytometry (Garner et al., 1986; Graham et al., 1990; Pintado et al., 2000; Arruda et al., 2003).

Integrity of the acrosome might be verified by different fluorescence techniques (Thomas et al., 1997). The most applied is that use glycoprotein markers, as lectins (Graham et al., 1990), among them, the Pisum sativum agglutinin (PSA) has been widely used (Cross and Meizel, 1989), which is fluorescein-conjugate, as fluorescein isothiocyanate (FITC) (Holden et al., 1990). The PSA is an agglutinin from edible pea and binds to glycoconjugates of acrosomal matrix (Cross and Meizel, 1989); it has affinity for terminal $\alpha$ D-glucosyl and $\alpha$-D-mannosyl residues of glycoproteins, and binds specifically to the sugar $\alpha$-mannoside found in the acrosomal contents (Cross et al., 1986). This agglutinin, when bound to FITC, marks damaged sperm acrosome in yellow-green (Cross et al., 1986; Graham et al., 1990; Celeghini et al., 2007).

A special type of multimer of carbocyanines, identified as $5,5^{\prime}, 6,6^{\prime}$-tetrachloro-1,1',3,3'tetraethylbenzimidazolyl carbocyanine iodide (JC-1), has been accurately used as a sensitive measure to detect changes in sperm mitochondrial membrane potential in several species (Garner et al., 1997; Gravance et al., 2000; Andrade et al., 2007; Celeghini et al., 2007, 2008; Nascimento et al., 2008). JC-1 is a fluorescent probe able to detect at single cell level variations in mitochondrial membrane potential, by color code. Thus, the color of dye changes reversibly from green to red-orange as the mitochondrial membrane becomes more polarized (Cossarizza et al., 1993). The green fluorescence from JC-1 exists as a monomer at low membrane potential; while, the red-orange at high membrane potential from $\mathrm{JC}-1$ is due $\mathrm{J}$ aggregates formation (Haugland, 2001).

The fluorescent probe combination has been indicating to permit simultaneous evaluation from several sperm cell compartments (Graham et al., 1990; Centola et al., 1990; Sukardi et al., 1997; Thomas et al., 1997; Nagy et al., 2003; Andrade et al., 2007; Celeghini et al., 2007, 2008; Nascimento et al., 2008). Graham et al. (1990) demonstrated that at least three bovine sperm compartments can be simultaneously evaluated, by addition of three probes.

This experiment was designed to validate a simple and practical technique to simultaneous evaluation of plasmatic and acrosomal membranes integrity, as well as mitochondrial function in ram sperm by fluorescent probes association.

\section{MATERIAL AND METHODS}

Four ejaculates were obtained from three mature rams $(n=12)$. The collects of semen were performed once a week. Rams were selected from 12 animals and only ejaculates showing sperm motility $\geq 80 \%$ and abnormal morphology $\leq 10 \%$ were used.

After analyses, the semen was diluted in TALP sperm medium (Bavister et al., 1983), to a final concentration of $25 \times 10^{6}$ spermatozoa $/ \mathrm{mL}$. The diluted semen was split into two aliquots. One of them was maintained (fresh semen) and the other was submitted to flash frozen in liquid nitrogen and thawed, in three continuous cycles, to damage plasmatic and acrosomal membranes and to perturb the mitochondrial function. Fixed ratios of fresh semen:flash frozen semen were prepared to perform three treatments with the following ratios: 0:100 (T0), 50:50 (T50), and 100:0 (T100).

A stock solution of propidium iodide (PI) was prepared containing $25 \mathrm{mg}$ of $\mathrm{PI} / \mathrm{mL}$ of dimethyl sulfoxide (DMSO), and kept at $-20^{\circ} \mathrm{C}$. Then, 
work solutions were prepared, a solution with $0.5 \mathrm{mg}$ of $\mathrm{PI} / \mathrm{mL}$ of Dulbecco's phosphate buffer saline solution (DPBS). The work solution was stored at $-20^{\circ} \mathrm{C}$, in the dark.

A work solution of fluorescein isothiocyanatolabeled Pisum sativum agglutinin (FITC-PSA) was prepared containing $100 \mu \mathrm{g}$ of FITC-PSA $/ \mathrm{mL}$ of DPBS added of $10 \%$ of sodium azide solution at $10 \%$, aliquoted, and stored at $4^{\circ} \mathrm{C}$, in the dark.

A stock solution of 5,5',6,6'-tetrachloro-1,1',3,3'tetraethylbenzimidazolyl carbocyanine iodide (JC1) was prepared with $1.53 \mathrm{mM}$ of JC-1 in DMSO, and a work solution with $153 \mu \mathrm{M}$ of JC-1 in DMSO.

An aliquot of $150 \mu \mathrm{L}$ of diluted semen in TALP sperm medium $\left(25 \times 10^{6}\right.$ sperms $\left./ \mathrm{mL}\right)$ was put into a warmed microcentrifuge tube, and then added of $3 \mu \mathrm{L}$ of PI $(0.5 \mathrm{mg} / \mathrm{mL}), 3 \mu \mathrm{L}$ of JC- $1(153 \mu \mathrm{M})$, and $50 \mu \mathrm{L}$ of FITC-PSA $(100 \mu \mathrm{g} / \mathrm{mL})$. The sample was incubated for 8 minutes at $37^{\circ} \mathrm{C}$.

An $8 \mu \mathrm{L}$ sample was put on a slide, coverslipped, and immediately evaluated by epifluorescence microscopy (Nikon, model Eclipse 80i), in a triple filter (D/F/R, C58420), showing a set: UV-2E/C (340-380nm excitation and 435-485nm emission), B-2E/C (465-495nm excitation and 515-555nm emission), and G-2E/C (540-525nm excitation and $605-655 \mathrm{~nm}$ emission), considering the applied fluorochromes. Two hundred sperm cells per slide were examined at $1,000 \mathrm{x}$ magnification and classified based on the fluorescence emitted from each probe.
This experiment was designed with three treatments: T0, T50, and T100. The analyzed variables were: plasmatic membrane integrity, detected by PI inclusion of cell nucleus; acrosome integrity, detected by FITC-PSA stain; mitochondrial potential, determined by $\mathrm{JC}-1$; and sperm cell group with intact plasmatic membrane, intact acrosome, and high mitochondrial potential (IPIAH). The results were analyzed using the SAS/1998 program. Variables that did not meet statistical premises were arc-sin transformed. The original or transformed data were subjected, when necessary, to analysis of variance (ANOVA). The experimental model was as the following: $Y=\mu+T_{i}+B_{j}+e_{i j}$, in which $Y$ is the observation of treatment $i$ in block $j, \mu$ the general mean, $T_{i}$ the effect of treatment $i, B_{j}$ the effect of the block $j$ formed in function of the rams, and $e_{i j}$ is the unexplained error.

Means were compared by Fisher's LSD test. The data of plasmatic and acrosomal membranes integrity, mitochondrial potential, and IPIAH (dependent variables) in the treatments T0, T50, and T100 (independent variables) were submitted to simple linear regression analysis. All statistical analyses were calculated with a significance level at $5 \%$.

\section{RESULTS}

Fluorescent probes associations (PI/FITC-PSA/JC1) resulted in the classification of sperm cells in eight categories, according to emitted fluorescence by each probe (Table 1). The stain standard of ram sperm cells in the association probes can be seen in Figure 1.

Table 1. Ram sperm classification according to fluorescent stain emitted in the combination of propidium iodide (PI), fluorescein isothiocyanate-conjugated Pisum sativum agglutinin (FITC-PSA), and JC-1 protocol

\begin{tabular}{lccc}
\hline Ram sperm & PI* & FITC-PSA** & JC-1 \\
\hline Intact plasmatic membrane, intact acrosome and high mitochondrial potential & - & - & red-orange \\
Intact plasmatic membrane, intact acrosome and low mitochondrial potential & - & - & green \\
$\begin{array}{l}\text { Intact plasmatic membrane, damaged acrosome; and high mitochondrial } \\
\text { potential }\end{array}$ & - & + & red-orange \\
$\begin{array}{l}\text { Intact plasmatic membrane, damaged acrosome; and low mitochondrial potential } \\
\text { Damaged plasmatic membrane, intact acrosome; and high mitochondrial }\end{array}$ & - & + & green \\
potential & + & - & red-orange \\
$\begin{array}{l}\text { Damaged plasmatic membrane, intact acrosome and low mitochondrial potential } \\
\text { Damaged plasmatic membrane, damaged acrosome; and high mitochondrial } \\
\text { potential }\end{array}$ & + & - & green \\
$\begin{array}{l}\text { Damaged plasmatic membrane, damaged acrosome and low mitochondrial } \\
\text { potential }\end{array}$ & + & + & red-orange
\end{tabular}

*PI positive (+): red stained nucleus; **FITC-PSA positive (+): yellow-green acrosome region. 

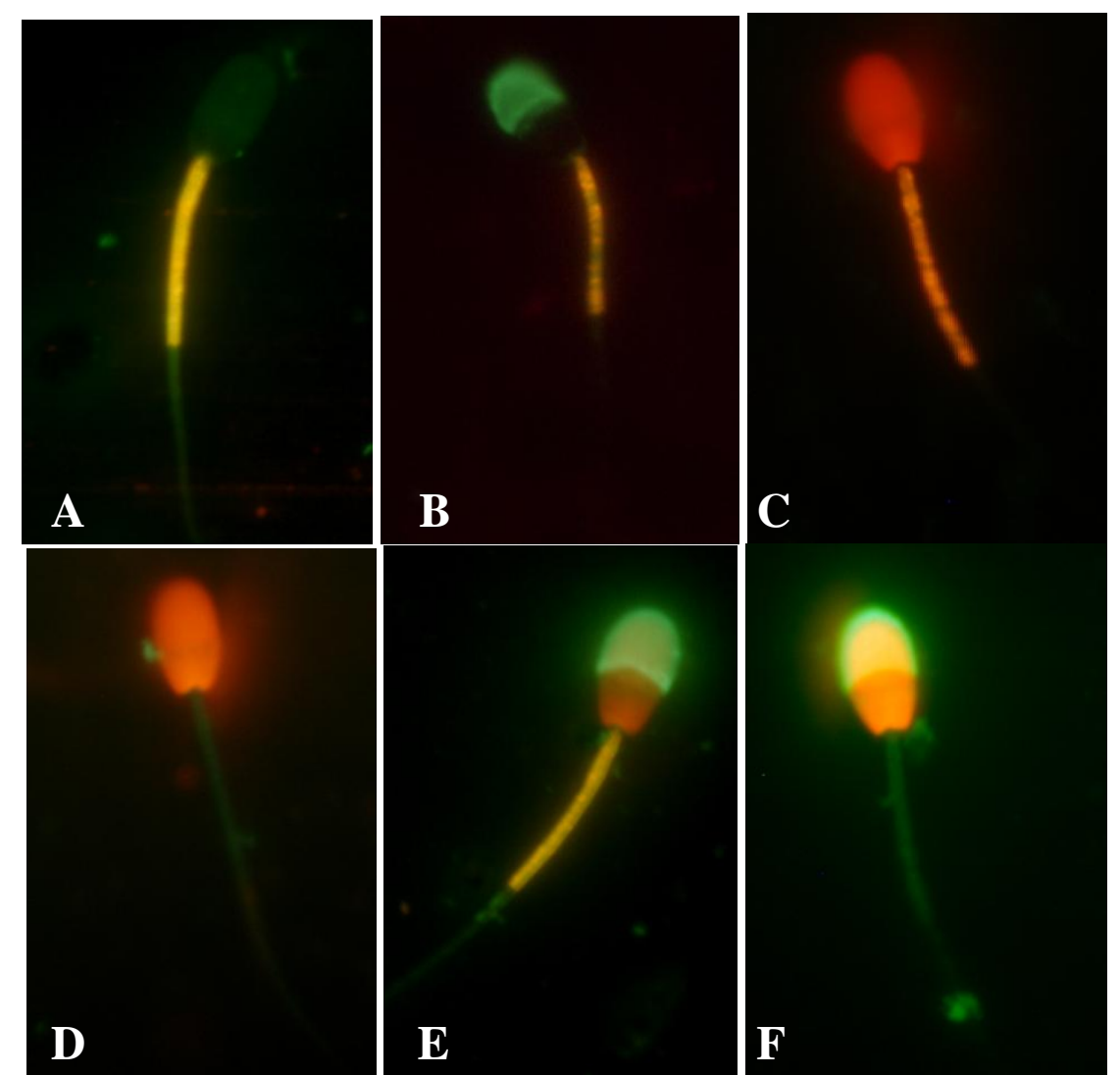

Figure 1. Epifluorescence photomicrography of ram spermatozoa stained with the association of fluorescent probes, PI, FITC-PSA, and JC-1 (1,000x magnification). A. Intact plasmatic and acrosomal membranes with high mitochondrial membrane potential. B. Intact plasmatic membrane, damaged acrosome with high mitochondrial membrane potential. C. Damaged plasmatic membrane, intact acrosome with high mitochondrial membrane potential. D. Damaged plasmatic membrane, damaged acrosome with low mitochondrial membrane potential E. Damaged plasmatic and acrosomal membranes with high mitochondrial membrane potential. F. Damaged plasmatic and acrosomal membranes with low mitochondrial membrane potential.

The effect of block (ram) was observed, but not significant interaction (block $\mathrm{x}$ treatment) was found. Significant effects were observed (ANOVA; $\mathrm{P}<0.0001)$ among treatments $\mathrm{T} 100$, T50, and T0 to mean percentage of spermatozoa showing plasmatic membrane integrity, acrosome integrity, high mitochondrial membrane potential, and IPIAH. Treatments differed significantly (Fisher test, $\mathrm{P}<0.001$ ) between them, as showed in Table 2 .

Table 2. Mean \pm standard deviation of ovine sperm intact plasmatic membrane, intact acrosome, mitochondrial function, and IPIAH $^{1}$ in T0 (fresh semen:flash frozen semen, 0:100), T50 (fresh semen:flash frozen semen, 50:50), and T100 (fresh semen:flash frozen semen, 100:0) treatments

\begin{tabular}{lccc}
\hline Characteristic & $\mathrm{T} 0$ & $\mathrm{~T} 50$ & $\mathrm{~T} 100$ \\
\hline Intact plasmatic membrane & $0.08 \pm 0.19 \mathrm{a}$ & $46.46 \pm 6.17 \mathrm{~b}$ & $86.79 \pm 4.92 \mathrm{c}$ \\
Intact acrosome & $1.33 \pm 0.88 \mathrm{a}$ & $51.61 \pm 5.09 \mathrm{~b}$ & $93.33 \pm 2.89 \mathrm{c}$ \\
High mitochondrial membrane potential & $0.70 \pm 2.14 \mathrm{a}$ & $49.41 \pm 6.42 \mathrm{~b}$ & $90.91 \pm 5.42 \mathrm{c}$ \\
IPIAH & $0.08 \pm 0.19 \mathrm{a}$ & $46.45 \pm 6.17 \mathrm{~b}$ & $86.79 \pm 4.91 \mathrm{c}$ \\
\hline
\end{tabular}

Different letters in the same row indicate statistical differences $(\mathrm{P}<0.0001)$.

IPIAH: Intact plasma membrane, intact acrosome, and high mitochondrial membrane potential. 
Linear analysis regression of different treatments (T0, T50, and T100) in the semen allowed to trace a line of regression to sperm characteristics evaluated by each probe (Figure 2). For plasmatic membrane integrity, detected by PI probe, it was obtained the equation: $\hat{\mathrm{Y}}=1.09+0.86 \mathrm{X}$ and $\mathrm{R}^{2}=0.98$ (Figure 2A). The intact acrosome, detected by FITC-PSA probe

A
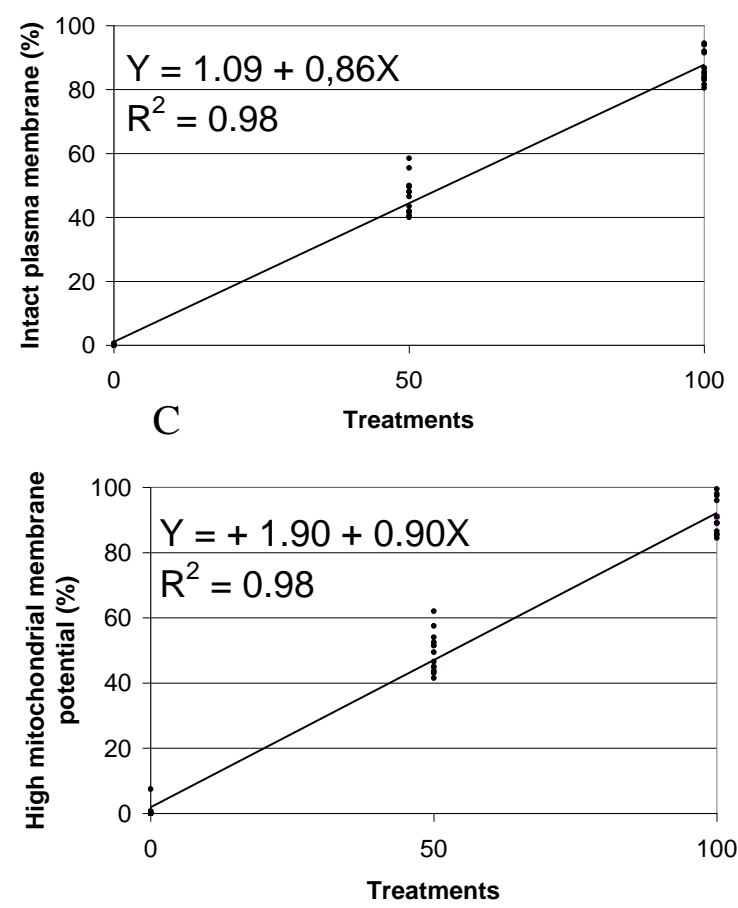

produced the equation: $\hat{\mathrm{Y}}=2.76+0.92 \mathrm{X}$ and $\mathrm{R}^{2}=0.98$ (Figure 2B). The high mitochondrial membrane potential, marked in red-orange by JC-1, was estimated by the equation: $\hat{\mathrm{Y}}=1.90+0.90 \mathrm{X}$ and $\mathrm{R}^{2}=0.98$ (Figure 2C). The IPIAH cells resulted in equation: $\hat{\mathrm{Y}}=1.09+0.86 \mathrm{X}$ and $\mathrm{R}^{2}=0.98$ (Figure 2D).

B

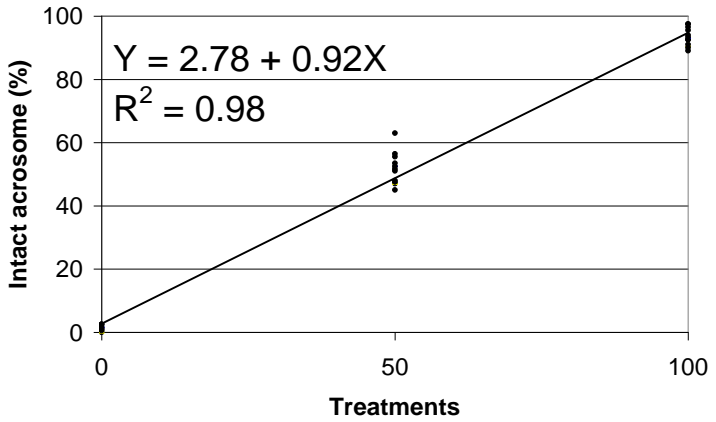

$\mathrm{D}$

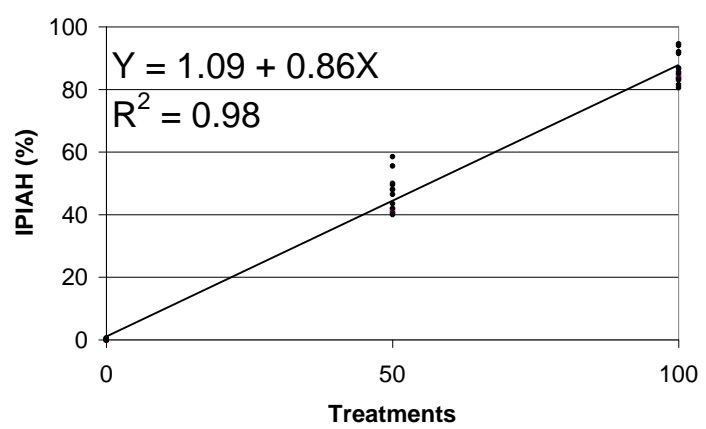

Figure 2. Linear regression of PI/FITC-PSA/JC-1 association, in ovine spermatozoa submitted to treatments T0 (fresh semen:flash frozen semen, 0:100), T50 (fresh semen:flash frozen semen, 50:50), and T100 (fresh semen:flash frozen semen, 100:0). A. Plasmatic membrane integrity, detected by exclusion of propidium iodide. B. Intact acrosome, detected by FITC-PSA. C. High mitochondrial membrane potential, determined by JC-1. D. Sperm showing intact plasma, intact acrosome, and high mitochondrial membrane potential (IPIAH), verified by PI/FITC-PSA/JC-1 association.

\section{DISCUSSION}

Fluorescent probes association was tested to simultaneous evaluation integrity of plasmatic and acrosomal membranes, as well as mitochondrial membrane potential, in this experiment. These tests are important to obtain techniques that show suitable results with the real status of each structure. Moreover, it is necessary identify which probe is better to associate; therefore, some probes when associated to others can present unlike results, changing its characteristics and its fluorescence standard.
The association of PI and FITC-PSA probes for the evaluation of plasmatic and acrosomal membranes integrity, respectively, has been reported for human (Centola et al., 1990), equine (Arruda et al., 2003), bovine (Graham et al., 1990), and ovine sperm (Sukardi et al., 1997). The association of an additional probe to evaluate the mitochondrial function was used for bovine (Celeghini et al., 2007), swine (Andrade et al., 2007), equine (Nascimento et al., 2008), and in this experiment was validated to be used in order to evaluate ram sperm. 
The results of ANOVA and Fisher test proved statistical differences among T0, T50, and T100 treatment groups, and then data could be submitted to linear regression analysis. The lines of regression were traced from different treatments in the semen (T0, T50, and T100) to sperm characteristics evaluated by each probe.

From the equation obtained in the regression analysis for plasmatic membrane integrity (Figure 2A), in this association, it is possible to verify that the value of interception (the point that the line crosses the $\mathrm{Y}$ axis, expressing the $\mathrm{Y}$ value when $X=0$ ) corroborates that the sample submitted to flash frozen treatment, to get the objective of damaging all membranes. In the same way, the value of regression coefficient (how much $\mathrm{X}$ varies in relation to $\mathrm{Y}$ ) reflects the T100, which represents a sample with at least $80 \%$ of motility. The high coefficient of determination confirms these observations. A similar result was reported for bovine (Celeghini et al., 2007) and swine (Andrade et al., 2007) sperm using the same association (PI, FITCPSA, and JC-1). Graham et al. (1990), who compared the efficiency of PI isolate with eosin/nigrosin stain technique, found positive correlation $(\mathrm{r}=0.78)$ between techniques. A positive correlation between PI and eosin/nigrosin was also observed in the spermatozoa of dogs $(r=0.88)$ (Peña et al., 1999), boars ( $\mathrm{r}=0.71)$, and bulls ( $\mathrm{r}=0.83$ ) (Pintado et al., 2000). Pintado et al. (2000) also found high positive correlations between $\mathrm{PI}$ and $\mathrm{H} 258$ in swine $(r=0.96)$ and bovine $(r=0.94)$ sperms.

Similar coefficients were observed in the regression equation for acrosomal integrity (Figure 2B), the high determination coefficient evidences the efficiency of the technique. The FITC-PSA efficiency was evaluated by Graham et al. (1990) comparing it to naphthol yellow/erythrosin b (Andrade et al., 2007; Celeghini et al., 2007).

Similar results about the equation of mitochondrial function evaluated by JC-1 (Figure 2C) in this experiment were obtained by Garner et al. (1997) when associated PI with R123, MITO, or JC-1 in bovine sperm. They verified that the association was possible and that JC-1 showed an advantage on R123 and MITO. Analog result was found by Gravance et al. (2000), which validate JC-1 to evaluate mitochondrial function of equine sperm $\left(\hat{\mathrm{Y}}=8.36+0.84 \mathrm{X}, \mathrm{R}^{2}=0.97\right)$. It is important to consider that the JC-1 is different of others mitochondrial function probes, because it identifies two mitochondrial populations: one with high mitochondrial membrane potential (mitochondria stained in red-orange) and another with low mitochondrial membrane potential (mitochondria stained in green).

Similar treatment performed in this experiment was found by Thomas et al. (1997) to evaluate PI, SYTO-17, and FITC-PNA association. This association allowed only evaluating of plasmatic and acrosomal membranes in bovine sperm. The percentage of live sperm, stained by SYTO-17 in 100:0, 50:50, and 0:100 (ratio of live:dead spermatozoa) treatment groups, was 84, 37, and $4 \%$, respectively. These results were similar to those obtained in this experiment to plasmatic membrane integrity.

Celeghini et al. (2007) found equations resembling the ones obtained in this experiment using similar probe associations for bovine sperm cells. However, these authors added the use of the probe $\mathrm{H} 342$. For plasmatic membrane integrity, detected by PI and H342 probes, Celeghini et al. (2007) found the equation $\hat{\mathrm{Y}}=0.78+0.92 \mathrm{X}$ with $\mathrm{R}^{2}=0.92$. The intact acrosome, verified by FITC-PSA probe, produced the equation: $\hat{\mathrm{Y}}=3.82+0.81 \mathrm{X}$ with $\mathrm{R}^{2}=0.91$. The high mitochondrial potential, marked in red-orange by $\mathrm{JC}-1$, was estimated by the equation: $\hat{\mathrm{Y}}=0.06+0.78 \mathrm{X}$ with $\mathrm{R}^{2}=0.93$. Nevertheless, it is important to remember that the addition of one more probe (H342) increases the technique cost and did not show any advantage in relation to the technique introduced in this work.

All laboratorial tests search to predict the fertilizing capability of the semen. The technique described in this work displayed very satisfactory results on plasmatic, acrosomal, and mitochondrial membranes status in ram spermatozoa; however, a fertility test would be of great value to define if such technique reflects really the semen fertilizing potential. Tartaglione and Ritta (2004) observed that plasmatic and acrosomal membranes integrity was more correlated to in vitro fertilizing rate than sperm motility and morphology. These authors observed that the combination of the 
eosin/nigrosin stain with hypoosmotic swelling test showed correlation coefficient of $78 \%$ at in vitro fertilization rate. When these results were included in the regression model joined with the results of Trypan Blue/Giemsa, which evaluate plasmatic and acrosomal membranes, this coefficient increased to $82.4 \%$. These results might suggest that higher number of analyses performed increases the predict fertility capability.

The simultaneous assessment of plasmatic and acrosomal membranes integrity, as well as mitochondrial function, increase the accuracy of semen analyses, because it could be provide the percentage of sperm cells in the sample with oocyte fertilizing capability.

\section{CONCLUSION}

The novel technique described here could be an useful tool in sperm ram evaluation and for new research in semen biotechnology for ram as well.

\section{ACKNOWLEDGMENTS}

The authors would like to thank FAPESP (Brazil) for the financial support, processes 00/14653-6 and 01/13940-4.

\section{REFERENCES}

ANDRADE, A.F.C.; ARRUDA, R.P.; CELEGHINI, E.C.C. et al. Fluorescent stain method for the simultaneous determination of mitochondrial potencial and integrity of plasma and acrosomal membranes in boar sperm. Reprod. Domest. Anim., v.42, p.190-194, 2007.

ARRUDA, R.P.; BALL, B.A.; GRAVANCE, C.G. et al. Flow cytometric determination of plasmatic membrane and acrosomal integrity of the stallion spermatozoa. Acta Sci. Vet., v.31, p.226-227, 2003.

BAVISTER, B.D; LEIBFRIED, M.L.; LIEBERMAN, G. Development of preimplantation embryos of the golden hamster in a defined culture medium. Biol. Reprod., v.28, p.235-247, 1983.

CELEGHINI, E.C.C.; ARRUDA R.P.; ANDRADE, A.F.C. et al. Effects that bovine sperm cryopreservation using two different extenders has on sperm membranes and chromatin. Anim. Reprod. Sci., v.104, p.119-131, 2008.
CELEGHINI, E.C.C.; ARRUDA, R.P.; ANDRADE, A.F.C. et al. Practical techniques for bovine sperm simultaneous fluorimetric assessment of plasma, acrosomal and mitochondrial membranes. Reprod. Domest. Anim., v.42, p.479-488, 2007.

CENTOLA, G.M.; MATTOX, J.H.; BURDE, S. et al. Assessment of the viability and acrosome status of fresh and frozen-thawed human spermatozoa using single-wavelength fluorescence microscopy. Mol. Reprod. Dev., v.27, p.130-135, 1990

COSSARIZZA, A.; BACCARANI-CONTRI, M.; KALASHNIKOVA, G. et al. A new method for the cytometric analysis of mithocondrial membrane potencial using the J-aggregate forming lipophilic cation 5,5',6,6'-tetrachloro1,1',3,3'-tetraethylbenzimidazolcarbocyanine iodide (JC-1). Biochem. Biophys. Res. Commun., v.197, p.40-45, 1993.

CROSS, N.L.; MEIZEL, S. Methods for evaluating the acrossomal status of mammalian sperm. Biol. Reprod., v.41, p.635-641, 1989.

CROSS, N.L.; MORALES, P.; OVERSTREET, J.W. et al. Two simple methods for detecting acrosome-reacted human sperm. Gamete Res., v.15, p.213-226, 1986

GARNER, D.L.; PINKEL, D.P.; JOHNSON, L.A. et al. Assessment of spermatozoal function using dual fluorescent staining and flow cytometric analysis. Biol. Reprod., v.34, p.127138, 1986.

GARNER, D.L.; THOMAS, A.C.; JOERG, H.W.et al. Fluorometric assessments of mitochondrial function and viability in cryopreserved bovine spermatozoa. Biol. Reprod., v.57, p.1401-1406, 1997.

GRAHAM, J.K.; KUNZE, E.; HAMMERSTEDT, R.H. Analysis of sperm cell viability, acrosomal integrity, and mitochondrial function using flow cytomitry. Biol. Reprod., v.43, p.55-64, 1990.

GRAVANCE, C.G.; GARNER, D.L.; BAUMBER, J. et al. Assessment of equine sperm mitochondrial function using JC-1. Theriogenology, v.53, p.1691-1703, 2000.

HAUGLAND, R.P. Handbook of fluorescent probes and research chemicals. 8.ed. Eugene, OR: Molecular Probes, 2001. 
HOLDEN, C.A.; ROSS, V.H.; SATHANANTHAN, A.H. et al. Assessment of the human sperm acrosome reaction using concavalian A lectin. Mol. Reprod. Dev., v.25, p.247-257, 1990.

NAGY, S.; JANSEN, J.; TOPPER, E.K. et al. A triple-stain flow cytometric method to assess plasma -and acrosome membrane integrity of cryopreserved bovine sperm immediately after thawing in presence of egg-yolk particles. Biol. Reprod., v.68, p.1828-1835, 2003.

NASCIMENTO, J.; ANDRADE, A.F.C.; RAPHAEL, C.F. et al. Effects of sperm concentration and volume of straws on motion characteristics and plasma, acrosomal and mitochondrial membranes of equine cryopreserved spermatozoa. J. Equine Vet. Sci., v.28, p.351-358, 2008.

PEÑA, A.L.; QUINTELA, L.A.; HERRADÓN, P.G. Flow cytometric assessment of acrosomal status and viability of dog spermatozoa. Reprod. Dom. Anim., v.34, p.495-502, 1999.
PINTADO, B.; DE LA FUENTE, J.; ROLDAN, E.R.S. Permeability of boar and bull spermatozoa to the nucleic acid stains propidium iodide or Hoechst 33258, or the eosin: accuracy in the assessment of cell viability. J. Reprod. Fertil., v.118, p.145-152, 2000.

SUKARDI, S.; CURRY, M.R.; WATSON, P.F. Simultaneous detection of the acrosomal status and viability of incubated ram spermatozoa using fluorescent markers. Anim. Reprod. Sci., v.46, p.89-96, 1997.

TARTAGLIONE, C.M.; RITTA, M.N. Prognostic value of spermatological parameters as predictors of in vitro fertility of frozen-thawed bull semen. Theriogenology, v.62, p.1245-1252, 2004.

THOMAS, C.A.; GARNER, D.L.; DEJARNETTE, J.M. Fluorometric assessments of acrossomal integrity and viability in cryopreserved bovine spermatozoa. Biol. Reprod., v.56, p.991-998, 1997. 